\title{
Teacher's Roles Implemented in Teaching Children and Teenager Classes in Petra Language Center (PLC)
}

\author{
Evelyn Listiyani ${ }^{1}$, Julia Eka Rini ${ }^{2}$ \\ English Department, Faculty of Languages and Literature, Petra Christian University, Siwalankerto 121- \\ 131, Surabaya 60236, INDONESIA \\ E-mail: evelynlistiyani09@gmail.com; jerini@petra.ac.id
}

\begin{abstract}
This study analyzed the implementation of teacher's roles at Petra Language Center (PLC). There were two classes with five to six students in each class taking part in this study. The main theories for this study are from Harmer's (2001 \& 2007) on teacher's roles. The method used was qualitative approach. The researcher investigated the teacher's roles implemented in children and teenager classes and analyzed the similarities and differences. The findings revealed that there are several similarities and differences. The main similarity is that the teacher implemented the same number of teacher's roles types for both classes. The second one is that the teacher's role as an organizer was more or less equally the same. The differences are in the number of occurrence of each type, the context and the way the teacher implemented those roles in both classes. Additionally, the findings also showed that the most important thing is that the teacher should be able to adjust the roles according to the classroom situation and activities.
\end{abstract}

Keywords: Teacher's roles, children class, teenager class, similarities and differences of teacher's roles

\section{INTRODUCTION}

Harmer (2001) stated that teacher's roles are very important in the teaching and learning process in class. The importance of teacher's roles lies in the point that they should facilitate the students' progress in learning as he emphasized in his book that all roles, after all, aim to facilitate the students' progress in some way or another (2001, p.57). Therefore, in a classroom with students of the same age, the roles of teachers may change from one activity to another so that the teaching learning process can be effective. "What we can say, with certainty, is that we need to be able to switch between the various roles we have described here, judging when it is appropriate to use one or other of them" (Harmer, 2001, p.63). The implementation of these roles will indeed influence the teaching and learning process in class in the sense that they help students in receiving knowledge in the classroom according to their different backgrounds. Besides students' different backgrounds, With students of different ages, it is important for teachers to consider the age of the students in implementing the teacher's roles according to Glatter, Deruy, \& Wong (2016). They say that when dealing with elementary-aged children, teachers usually focus more on the development of the children and tend to play the roles of an observer and a prompter. However, in teaching high-school students, teachers are more likely to be a content expert in the subject in which the teacher plays the role of a resource person. There are also times when teachers have to act as a prompter; on other occasions, it will be more appropriate to act as a controller. In this study, the writer wanted to find out the similarities and differences of teacher's roles in teaching children and teenager classes. In answering the research questions, the researcher used the theory on the types of teacher's roles from Harmer (2001 \& 2007).

According to Harmer (2001 \& 2007), teachers have eight roles: controllers, organizers, assessors, prompters, participants, resource persons, tutors, and observers. The teacher acted as 
a controller when the teacher is in charge of the teaching and learning process, leads from the front, and commands the students to do things. In this role the teacher commands the students to do things and manages all class activities. Since the teacher acts as the controller of the classroom, it is called teacher-fronted classroom (Harmer, 2007, p.108). The role of an organizer is carried out when (Harmer, 2001, p. 58). When the teacher assesses the students' work, offers feedback, and grades students, his/her role is considered as an assessor. As an assessor, the teacher evaluates how well students are performing or how well they performed. However, the teacher should consider whether the feedback and correction that he/she gives are able to increase the students' motivation or not (Harmer, 2001, p. 59). Another teacher's role is a prompter. In this role the teacher helps the students by prompting, namely offering words or phrases at the time they are having difficulties. When the teacher prompts, he/she should be able to encourage the students, but with discretion. By doing that, the students can get the right amount of encouragement and give initiative and participate (Harmer, 2007, p. 109). The next type is that the teacher acted as a participant. This happens when the teacher participates in the students' activity. By participating along with students, the teacher can brighten up the atmosphere in order to make the classroom activities more engaging and interesting to the students (Harmer, 2007, p. 109). Another role is a resource person; the teacher provided information needed by the students. The teacher's duty is to provide all the information that the students need. The teacher acts as a reliable resource when the students encounter difficulties (Harmer, 2007, p. 110). The teacher acted as a tutor when the teacher helps the students one by one in private. In this role, the teacher in a personal contact, helps and supports the students when they are having difficulties. For example, when the students are working with their research writing, or presentation, the teacher can lead them to ideas that they have never thought of (Harmer, 2007, p. 110). Finally, as an observer, the teacher investigates students in class and gives individual feedback. According to Harmer, "We will want to observe what students do (especially in oral communicative activities) so that we can give them useful group and individual feedback" (Harmer, 2001, p. 62). To make it easier for the writer to analyze the data in the research, the key characteristics of each type of teacher roles according to Harmer's (2001 $\&$ 2007) are put in the following table.

Table 1. The Key Characteristics of each Type of Teacher Roles

\begin{tabular}{|c|c|c|}
\hline 1. & Controller & $\begin{array}{l}\text { - In charge of the teaching and learning process } \\
\text { - Lead from the front } \\
\text { - Take the register, command students things, organize drills, read aloud }\end{array}$ \\
\hline 2. & Organizer & $\begin{array}{l}\text { - Give instruction on how the students are going to do the activity } \\
\text { - Put them into pairs or groups and close things down when it is time to } \\
\text { stop }\end{array}$ \\
\hline 3. & Assessor & $\begin{array}{l}\text { - Check students' answers, offer feedback, and grade students in various } \\
\text { ways } \\
\text { - Give evaluation to the students }\end{array}$ \\
\hline 4. & Prompter & $\begin{array}{l}\text { - Offer words or phrases by the time the students are having difficulties } \\
\text { - Help students to proceed in class }\end{array}$ \\
\hline 5. & Participant & $\begin{array}{l}\text { - Engage in students' activity } \\
\text { - Participate with the students }\end{array}$ \\
\hline 6. & Resource & $\begin{array}{l}\text { - Act as a reliable resource when the students asked questions } \\
\text { - Provide needed information by explaining the materials of the lessons }\end{array}$ \\
\hline 7. & Tutor & $\begin{array}{l}\text { - Help students one by one when they have difficulties in private } \\
\text { - Go around in the classroom and explain the material to the students one } \\
\text { by one }\end{array}$ \\
\hline
\end{tabular}




\begin{tabular}{|l|l|l|}
\hline 8. & Observer & $\begin{array}{l}\bullet \text { Give an individual feedback } \\
\bullet\end{array}$ \\
& & Investigate students in class \\
\hline
\end{tabular}

The key characteristics of each type of teacher roles based on Harmer (2001 \& 2007) in the table above is used to analyze the teacher's utterances obtained from the classroom observation.

\section{METHODS}

In this study, the researcher used a qualitative approach. According to Hancock, Ockleford, \& Windridge (2009, p.6), "qualitative research studies behavior in natural settings or uses people's accounts as data", usually with no manipulation of variables. It is considered as qualitative research because the writer of this study collected the data from the class observation which were done in natural settings and used the teacher's utterances. The result of the classroom observation was used as the data in finding the teacher's roles in teaching students with different ages.

The reasons the writer decided to do the observation at PLC were as follows. PLC is a language course at Petra Christian University. The university itself is officially accredited and acknowledged by the Ministry of Research, Technology and Higher Education of the Republic of Indonesia (uniRank, 2019). As stated on the website (http://ppb.petra.ac.id/), PLC was established in 2009. In fact, PLC has a former name of Program Pendidikan Bahasa, known as $P P B$ even before the year of 2000. Since 2009, it has been changed into Petra Language Center (PLC). Since it has existed for years, the writer had the opinion that PLC is an established institution in terms of the quality of the teachers, materials, and facilities. PLC teachers must also have a lot of experiences and skills in teaching students. Therefore, she chose to observe classes at PLC and a teacher at PLC. There were approximately 10 classes of children and teenager classes. The writer chose to observe Children 7A that had 5 students and Teenager 1A that had 7 students because both classes were taught by the same teacher. In this way it would be clear that the roles were different if the students' ages were different.

In collecting the data, the method used was class observation and the writer observed the classes as non-participant. The observation was conducted twice for each class on October 14 and 17, 2019 because on those dates the teacher did similar activities. She began to explain the material, got to know the students and also helped students do the exercises. The researcher recorded the teacher's utterances when she was teaching the classes. The children class lasted 60 minutes and the teenager class 90 minutes. Later, the recorded data were transcribed using clean transcription. The writer used clean transcription-not including the grammatical mistakes, false start, and repetitions, because the writer only wanted to observe the teacher's roles. Then, the transcriptions were moved to the analysis table below.

Table 2. The Analysis of Teacher's Roles in Children/Teenager Class

\begin{tabular}{|c|c|c|c|}
\hline Code & Teacher's Utterances & Teacher's Roles & Notes \\
\hline & & & \\
\hline & & & \\
\hline
\end{tabular}

The code column represented the code number of the teacher's utterances and meetings since there were two meetings and a lot of teacher's utterances. The teacher's utterance column was used to place the teacher's utterances in the classroom. The column of the teacher's roles was used to state which roles that the teacher played according to the utterances. The writer, there were 40 teacher's utterances found in children class and 46 teacher's utterances found in teenager class. The note column contained the reasons why the writer chose a certain type of 
teacher's role. This table is the sample table for all teacher's roles analysis tables. The writer then analyzed all the teacher's roles based on the theory of the teacher's roles. To count the teacher's roles percentages for each class, this formula was used.

Types of teacher's roles that occurred in each class x $100 \%$

Total numbers of each type of teacher's roles

\section{FINDINGS AND DISCUSSION}

In this part, the examples of the teacher's utterances and the roles she played are given. Then, the similarities and differences drawn from the occurrence of the roles of the teacher are discussed.

\section{The Teacher's Utterances and the Roles}

The first example is the teacher's utterance in children class, "Read the diary and number the events of Samuel's life in order". In this case, the teacher implemented both controller and organizer roles since she commanded the students to read the diary and gave instruction on how the students should do the exercise by numbering the events of Samuel's life in order. Whereas, in the teenager class, the teacher said, "Okay, let's do part 1A. Let's do it together". In this context, the teacher only asked the students to do the exercise part $1 \mathrm{~A}$ without explaining further instruction on how they should do the exercise. The teacher commanded the students to do things and often directly followed by giving instruction which was the role of organizer in class. Children students need a detailed instruction in order for them to be able to proceed in class. However, in the teenager class, the teacher asked the students to do things and they did it without many difficulties since they were more mature than the children students; therefore, they directly did what the teacher asked without asking as many questions as children students.

The second example is the implementation of the organizer role in both classes. In children class, the teacher said, "Try to make questions from the prompt. Prompt itu 'patahan-patahan kata." The context is about the teacher who was explaining the instruction in the book regarding one of the exercises. In the teenager class, however, the teacher explained the instruction regarding the mid-term test, "Miss jelasin tentang UTS Speaking (I will explain about your Speaking Mid-Term exam). Your speaking test will be about making presentation about famous person's biography. Contohnya kayak ini tadi John Lennon (For instance, John Lennon that we've discussed earlier). You need to bring the picture of him/her. Terus setelah itu, (after that,) you need to make explanation about his/her biography. Jadi, misalnya 'This is Brad Pitt' (So, for example 'This is Brad Pitt'). Dia lahir dimana, latar belakang keluarganya seperti apa, main film apa aja, karya nya dia apa aja, dia menikah dengan siapa, punya anak berapa (When he was born, what his background is, what movie he starred in, his works, his partners, who his children are, and so on). Pokoknya biografi nya tentang orang tersebut (In short, the biography of that person). I expect your draft, seperti coretan-coretannya itu Kamis depan (I expect your draft, it's like your rough design, on next Thursday). Jadi dibikin di rumah, nanti Kamis depan baru kita cek draftnya (So, you need to do it at home and we will check the draft on next Thursday)". The teacher gave a detailed instruction to the students since it was related to their mid-term test. For the organizer role, the teacher is supposed to implement it more in the children class since the students were more likely to ask questions regarding the instruction. However, at that time, the teacher was explaining the instructions regarding the final exam in teenager class, but not in children class. Therefore, the number of occurrence of the organizer role in teenager class was higher than in children class. 
The third example is the teacher's utterances in children class which is, "ofis, not offais". In this context, the teacher offered feedback by correcting the students' mistake in reading the word 'office'. However, in teenager class, the teacher said, "Jonathan, soal nya 'are you playing?' No, I don't itu don't nya kamu dapet dari mana? (Jonathan, the question is 'are you playing?' No, I don't. Where do you get the word 'don't'?)'. In this context, the teacher checked the students' answers and offered feedback by correcting the mistakes. For the role of assessor, the teacher was paying more attention in the pronunciation of children students. The teacher tended to correct pronunciation in children class, rather than in teenager class. The teacher focused more on the grammar explanation and vocabularies in teenager class.

The fourth example is the implementation of the resource role in both classes, Firstly, in children class, the utterance is "Possession means kepemilikan / harta benda (the meaning in Indonesia). Parmesan cheese itu keju parmesan (the meaning in Indonesia)". The context is the teacher gave information regarding the students' question about the meaning of vocabularies. Whereas, in teenager class, the teacher said, "Homicide itu pembunuhan ya. Kalau commit suicide itu bunuh diri (Homicide is 'pembunuhan' (the meaning in Indonesia)). If commit suicide, it is 'bunuh diri' (the meaning in Indonesia))". In this case, the teacher gave information about the meaning of 'homicide' and 'commit suicide'. Finally, for the resource role, there were not many differences found between the children and teenager classes. The teacher just explained the material and asked if there were any difficulties in both classes.

The researcher found similarities and differences in the implementation of teacher's roles in children and teenager classes. To summarize, the researcher provided the table of general findings of the types of teacher's roles implemented by the teacher in both classes.

In terms of the activities in the classroom, the teacher mostly asked the students to do the exercises from their book. The teacher often called the students one by one to answer questions. However, the teacher gave a chance to the students to try to answer the questions by themselves first, rather than directly help them by the time they were having difficulties. Then, if the students could not answer the questions, it was time for the teacher to help them. Besides that, the teacher also rarely participated in the class. The teacher mostly asked students to do things and checked their work. Therefore, the teacher only led the activities in class from the front without directly taking part in the students' activities. Therefore, the prompter and participant roles were not implemented in both classes.

In terms of teaching, the teacher tended to lead from the front in both classes. The teacher rarely went around the classroom to observe the students one by one, rather the teacher taught the materials from the front. When the students were asked to do exercises and had done it, the teacher usually asked them to come forward and checked the students' works. Therefore, instead of going around in class, the teacher asked the students to come forward. In this context, the teacher did not implement the tutor and observer roles in both classes.

There are some similarities and differences that can be seen in table 3 below.

Table 3. Summary of Types of Teacher's Roles and Classes 


\begin{tabular}{|c|c|c|c|c|}
\hline \multirow{2}{*}{ Teacher's Roles } & \multicolumn{2}{|c|}{ Children class } & \multicolumn{2}{|c|}{ Teenager class } \\
\hline & Frequency & Percentage & Frequency & Percentage \\
\hline Controller & 11 & $27.5 \%$ & 17 & $36.9 \%$ \\
\hline Organizer & 8 & $20 \%$ & 10 & $21.7 \%$ \\
\hline Assessor & 8 & $20 \%$ & 3 & $6.5 \%$ \\
\hline Prompter & \multicolumn{2}{|c|}{ - } & \multicolumn{2}{|c|}{ - } \\
\hline Participant & \multicolumn{2}{|c|}{ - } & \multicolumn{2}{|c|}{-} \\
\hline Resource & 13 & $32.5 \%$ & 16 & $34.7 \%$ \\
\hline Tutor & \multicolumn{2}{|c|}{-} & \multicolumn{2}{|c|}{-} \\
\hline Observer & \multicolumn{2}{|c|}{-} & \multicolumn{2}{|c|}{-} \\
\hline Total & 40 & $100 \%$ & 46 & $100 \%$ \\
\hline
\end{tabular}

From table 3 above it can be seen that the difference lies in the frequency.

The clearest similarity is about the types of the role. The type of teacher's roles in both the children and teenager classes were the same, in terms of what were implemented and what were not. In both classes the teacher played the role of controller, organizer, assessor, and resource and in both classes the teacher did not implement the role of prompter, participant, tutor, and observer. The age difference did not influence the teacher in this sense.

The second similarity is about the organizer role. In children class it occurred $20 \%$ and in teenager class $21.7 \%$. it is almost similar. This means that in both classes the teacher gave instructions on how the students are going to do the activity. She also gave a clear instruction to the students before the students did their activities and made sure that all students understood her instruction. The teacher also gave information to the students regarding how to do the activity, divided the students into groups, and told them when to stop doing the activity.

The third similarity is that the differences of the occurrence of both the roles of resource and controller seen in each class were not really significant. In the teenager class the teacher's role mostly used was controller; controller was $36.9 \%$ and resource was $34.7 \%$ and in the children class resource was $32.5 \%$ and controller was $27.5 \%$. The theory says that teacher acts as a controller when the teacher is in charge of the teaching and learning process, leads from the front, and commands the students to do things, and manages all class activities, while as a resource person, the teacher's duty is to provide all the information that the students need when the students encounter difficulties. The similarity can be interpreted that the teacher managed class activities in both children and teenager classes. The difference was, indeed, more significant in the children class than the teenager class since in the children class the difference reaches five percents. This means that in the children class the teacher provided more information to the children when they encountered difficulties than only led the class from the front. This is strengthened by the difference of the most occurred types of roles. The most occurred in the children class was resource (32.5\%) while in the teenager class it was controller (36.9\%); it is the other way round. In the teenager class the two roles were somewhat balanced. The other roles were below the percentages of controller and resource.

An interesting difference to discuss is the assessor role. As an assessor, the teacher evaluates how well students are performing or how well they performed. When this role occurred $20 \%$ in children class and $6.5 \%$ in teenager class, it can be said that the teacher was more concerned with the children, whether they had done well what they were told to do or not. In the teenager class this was not the teacher's attention.

\section{CONCLUSION}


In conclusion, this study was about teacher's roles implemented in children and teenager classes in Petra Language Center (PLC) and the similarities and differences found in the implementation of teacher's roles in both classes. The theory applied in this study was types of teacher's roles by Harmer ( $2001 \&$ 2007). The data were collected from the teacher's utterances in the class observation.

From the classroom observation and analysis, it was revealed that there were four teacher's roles played by the teacher in the children and teenager classrooms: controller, organizer, assessor, and resource. Those four roles can be found in the teacher's utterances in the classroom. The activities in both classes were reading a passage from the book and discussing exercises. The similarities found were the same types of teacher's roles implemented in both classrooms and there were not any participant, prompter, tutor, and observer roles implemented in both classrooms. Whereas, the differences found were the numbers of occurrence of each type of teacher's roles implemented in the classrooms and the context in which the teacher implemented the roles. In children class, the students often asked questions regarding the difficult vocabularies that they encountered in the reading passage.

Overall, based on the writer's research, it is the duty of the teacher to adjust the implementation of teacher's roles. Teacher should observe the classroom situation in order to be able to switch the roles between one activity to another. Apart from that, the teacher should also consider the age of the students. Throughout the class observation that the writer did, the teacher provided more instruction as an organizer towards the children students since they were more active to ask questions regarding the activities, whereas for teenager students, the teacher tended to act as a controller and resource. Teenager students were quieter, calmer, and more open to listen to their teacher. Therefore, it was easy to act as a controller to command teenager students to do things since they did it without much difficulties and rarely asked questions. Moreover, the teacher was more likely to be convenient in explaining the materials to the teenager students as a resource.

Children students may feel confused if there were some vocabularies that they did not understand the meaning. Therefore, in order to fulfill the students' need of understanding the meaning of the difficult vocabularies, the teacher gave information about the meaning of the vocabularies in which the teacher implemented resource role. This was the most dominant role implemented in children class because the job in giving information belonged to the role of resource.

On the other hand, in teenager class, the teacher tended to command students to do things. Teenager students rarely asked questions about the meaning of vocabularies because they might be more mature than children students. Teenager students might think that they were able to search the meaning on the internet by themselves. The teacher often asked the students to read a conversation, answer questions in the exercises, etcetera. This was the most dominant role implemented in teenager class because the job in commanding students to do things belonged to the role of controller.

For further research, the writer also hopes that there is more research on the implementation of teacher's roles in teaching students with different ages, in which this study focuses on children and teenager students. The implementation of teacher's roles is essential in the teaching and learning process, especially when dealing with students from different characteristics such as age, background knowledge, personalities, et cetera. Therefore, the researcher wants to conduct a further study about comparing the teacher's roles in teaching Communicative Language Teaching (CLT) towards Asian and Foreign students. The study will be comparing the implementation of teacher's roles towards students with different culture. 


\section{REFERENCES}

Glatter, H., Deruy, E., \& Wong, A. (2016, September 01). Disrupting the one-teacher standard. Retrieved from

https://www.theatlantic.com/education/archive/2016/09/disrupting- the-oneteacher-model/498197/

Hancock, Ockleford, \& Windridge (2009). An introduction to qualitative research. National Institute for Health Research. Retrieved from https://www.rds-yh.nihr.ac.uk/wpcontent/uploads/2013/05/5_Introduction-to-qualitative-research-2009.pdf

Harmer, J. (2001). The practice of English language teaching (3rd ed.). London: Longman

Harmer, J. (2007). The practice of English language teaching (4rd ed.). London: Longman.

Oliver, D., Serovich, J., \& Mason, T. (2005). Constraints and opportunities with interview transcription: towards reflection in qualitative research. Social Forces, 84(2), 12731289. doi: 10.1353/sof.2006.0023

Program Pendidikan Bahasa. (2009). Retrieved from http://ppb.petra.ac.id/ uniRank. (2019). Universitas Kristen Petra. Retrieved from https://www.4icu.org/reviews/2202.htm 